\title{
Organizational Studies in Higher Education: A Reflection on Historical Themes and Prospective Trends
}

\author{
Tatiana Fumasoli $^{\mathrm{a}}$ and Bjørn Stensaker ${ }^{\mathrm{b}}$ \\ ${ }^{a}$ Arena Centre for European Studies, University of Oslo, Arena, P.O. Box 1143 Blindern, Oslo 0318, \\ Norway. \\ E-mail: tatiana.fumasoli@arena.uio.no \\ ${ }^{\mathrm{b}}$ Department of Educational Research, University of Oslo, P.O.Box 1092 Blindern, Oslo 0317, Norway. \\ E-mail: bjorn.stensaker@ped.uio.no
}

Drawing from a seminal article by Burton Clark that appeared in 2004 in Higher Education Policy, this paper examines the influence of organization studies in higher education policy research over the last 25 years and highlights the potential contributions for future inquiry. It argues that analysis has mainly tackled policy reforms and their impact on universities and colleges. In so doing scholars have focused on external drivers of change, specifically on policy change, and on their structural impact. Hence research in higher education has somewhat neglected the complex reality of the university as an organization possessing its own structures, cultures and practices. This implies that national policy agendas have dominated organizational research in higher education, while the views of practitioners such as institutional managers and administrators have not been sufficiently addressed. By calling for an increased focus on the university as an organization, the article discusses the need to systematize organizational research around distinctive analytical dimensions. It finally proposes a research agenda tackling various aspects of organizational change in higher education.

Higher Education Policy (2013) 26, 479-496. doi:10.1057/hep.2013.25

Keywords: organizational studies; policy studies; organizational change; universities and colleges

\section{Introduction}

Studies of universities and colleges as organizations have been recurrent in higher education research for decades. Burton Clark $(1970,1972)$ pioneered research on higher education from a perspective built on organizational studies by providing systematic analysis through case studies on selected US higher education institutions. Later, in his 1998 and 2004 works on entrepreneurial universities, research on universities and colleges as organizations was further developed. The key messages from these books appeared in a 2004 article in Higher Education Policy entitled 'Delineating the Character of the Entrepreneurial University'.

In this article Clark (2004a, 355) asked two fundamental questions: How are entrepreneurial universities formed? How do they sustain themselves? In discussing 
Tatiana Fumasoli and Bjørn Stensaker

Organizational Studies in Higher Education

480

these questions, Clark emphasized that such universities are constructed through a combination of structural and cultural factors providing these universities with a distinctive identity that also enables them to maintain a steady and adequate state of change in a shifting environment. In the concluding section of the article, Clark argued that state-led reform measures are not appropriate for handling change since system-based policies always overlook the characteristics, dynamics and needs of the individual institution (Clark, 2004a, 367). In other words, Clark calls for a shift in the unit of analysis, giving prominence to the university as an open system with multiple reciprocal relations with its own environment (Scott, 2008). This conclusion is interesting in light of the 25th anniversary of Higher Education Policy since it may be interpreted as a critique to a dominant role of the state in higher education policy research. Furthermore, this appraisal has potential implications for the role of policyoriented research in higher education, particularly concerning its conceptual as well as methodological approaches.

Indeed, state-initiated reforms of higher education systems are a familiar topic within the field in the last couples of decades, and many of these have been described and analysed in Higher Education Policy. Conceptually, Clark calls for a more sophisticated balance between structure and agency: he underscores the potential leeway universities and colleges may hold in dealing with the legal and normative frameworks provided by their environment (see also Oliver, 1991).

This article picks up the challenge put forward by Clark, and aims to explore how organizational studies have been conceived in higher education by addressing three questions: (1) How can organization studies in higher education be categorized analytically? (2) How useful is this categorization to better understand and conceptualize organizational studies in higher education - using relevant studies published in Higher Education Policy the last 25 years as our key sample? (3) What are the possible implications of our analysis for future organization studies in higher education?

The article is structured according to our research questions. Hence, we start by offering a reflection on how we might develop relevant categorizations of organizational studies within our field, followed by a brief review of relevant organizational articles in the current journal over a 25-year period. We then discuss possible research areas and approaches missing in an organizational perspective before we end with a plea for a broadened research agenda.

\section{Organizational Perspectives in Higher Education Research - A Revisit to Weber, Durkheim and Issues of Power}

\section{Power and politics in higher education organizational research}

In a meta-reflection on developments in management studies a decade ago Stewart Clegg $(2003,537)$ pointed out that power and politics had hardly been systematically 
Tatiana Fumasoli and Bjørn Stensaker

addressed in this research area. He argued that the field of management research had not really dwelled on the underlying structures of ideology and influences forming the research agendas. In a similar vein but focusing more specifically on organizational studies Pfeffer (1997) observed that power-related issues have been neglected by scholars in the field.

In higher education studies, however, it could be argued that power relationships have been a highly investigated issue (starting with seminal works like Baldridge, 1971; Salancik and Pfeffer, 1974). It is quite easy to find numerous books and journals, including Higher Education Policy, that attempt to bring power-related issues to the forefront of the higher education research agenda against the backdrop of policy studies. In particular, the shifting configurations of actors in higher education have been scrutinized, in an attempt to understand, among other things, how winners and losers emerge from on-going modifications at system level (Musselin, 2001). In the same vein the implications of policy changes at institutional level have been explored (see for instance Amaral et al., 2003). Much of this research has focused on the mutual relationships between academics, managers and administrators, with an underlying assumption that on-going change was negatively affecting academic work, for instance by limiting academic freedom. In sum, research had tackled on one side the relationships among state, management and academics, on the other side the emerging patterns of coexistence between institutional leadership, administrators and academics within the university. Normative stances have often shaped the debate by contrasting managerialism and academic freedom, competition and cooperation, market $v s$ academic values, or, more in general, the characterization of the nature of the university within society, as an instrument to achieve broader societal objectives or as a value per se (Maassen and Olsen, 2007).

Typically, these studies analyse public reforms and discuss their potential consequences for higher education. Hence, issues concerning governance, organization and management are among those most frequently covered. This is not surprising for much higher education research is funded directly or indirectly by governments and often linked to instrumental aims and objectives (Schwarz and Teichler, 2000). Furthermore, changes in university governance, in the roles of academic leadership, in the funding models of the sector, and in the challenges facing the academic profession are among the topics that have been tackled. These pointed to important developments in the sector that have been studied in detail (see, e.g., Amaral et al., 2002, 2003; Teixeira et al., 2004; Huisman, 2009; Paradeise et al., 2009; Locke et al., 2011). More in general, the rise of managerialism and the wave of different reforms in the framework of the so-called New Public Management have been highlighted and the (different) effects on the functioning of higher education institutions have represented a major research topic (Braun and Merrien, 1999; Kehm and Lanzendorf, 2006). While not all of these studies can be labelled as pure organizational studies due to their focus on contextual factors, they systematically investigated how universities and colleges are coping with change triggered in their 
Tatiana Fumasoli and Bjørn Stensaker

Organizational Studies in Higher Education

482

broader environment. Particularly they have shed light on changes of institutional governance, of decision making and of patterns of leadership.

Some characteristics of the analysed literature are relevant to our discussion. On the one hand, organizational change in higher education institutions is observed because of changes in the environment, specifically due to policy reforms. Universities and colleges are accordingly assumed to be adaptive organizations and/ or reactive complex systems responding and adjusting to external shifts. On the other hand, scholars have focused more on structural and formal dimensions (see for instance the EUA reports on institutional autonomy, Estermann and Nokkala, 2009; Estermann et al., 2011). At the same time the role of an emerging university leadership has been highlighted by looking at how rectorates and boards take action in the new governance frameworks. Another traditional perspective in higher education studies, based on the sociology of the professions, has investigated changes in the academic profession, for example its status, relevance, identity and working conditions (Altbach, 1996; Kehm and Teichler, 2013; Teichler et al., 2013).

These studies could be criticized for being somewhat atomistic, since they provide only a partial and therefore limited picture of the changes the sector is exposed to by focusing on specific organizational functions such as funding, leadership, quality assurance, teaching and research (Tight, 2012). In order to bring new insights in higher education analysis, we argue that an organizational approach could integrate and combine structural, cultural and practice-related factors.

\section{Back to the classics: Weber and Durkheim}

Much influenced by the work of Philip Selznick (1949, 1957), Clark conceived organizational structures and processes as frames that are shaped and transformed by a distinct organizational identity and an organic organizational culture (see, for example, Clark, 1956, 1960, 1970, 1972, 1998, 2004b). Clark's vision of the university has implications on how change can be understood, for different drivers, actors and dynamics are at play in higher education. Indeed, such an approach incorporates the multiple components of higher education, which address university governance - structures and processes, leadership - at institutional and understructure level. What seems to be more innovative and fruitful to the ongoing debate is that such components also tackle organizational culture(s) - values, norms and beliefs to which organizational members refer to. Along the same line, different groups of actors, policymakers, academics, managers and administrators interact and shape the field of higher education. In sum, Clark points to further analytical dimensions through which universities and colleges can be investigated. Even though Clark can be criticized for his blurred characterization of actors, his holistic vision of the university can be helpful in grasping the complexity of higher education and its ongoing changes. 
Tatiana Fumasoli and Bjørn Stensaker

The approach adopted by Clark can be seen as linked to a Durkheimian perspective in which individual action is characterized as a part of a larger social web creating harmonic institutionalized structures, which often downplay factors such as power and politics. A potential corollary would be that the studies of Clark are actually less oriented towards politics, policymaking and power. Along this line, Clark's stance may be illustrated by an example. In his article in Higher Education Policy Clark pointed to 'the dynamics of mutually supporting interaction, the dynamic of perpetual momentum, and the dynamic of embedded collective volition' (Clark, 2004a, 362). The picture portrayed is of institutions in a smooth constant changing mode, beyond the pressure of public reform, driven by intra-organizational self-reliance and characterized by a certain degree of robustness. In such a framework, change is characterized as incremental and evolutionary.

However, organizational studies in higher education could be categorized in a different way. Using another classic sociological father as starting point - Max Weber - a quite different way to undertake organizational studies comes to the fore. For Weber (1978) issues of rationalization, bureaucracy, hierarchy and power are key elements. Weber saw bureaucracy and rationalization as unrelenting forces that will pervade eventually the Western world. Thus sources of control (and of change) of the university are located in the environment while the university is doomed to inertia in the iron cage of its structures and processes, or, in other words, in its institutional constraints. Interestingly, the relation between bureaucracy and education represents a major pillar in Weber's thought. Bureaucracy is in the end domination by knowledge, where officials are trained in specific fields to fulfill their expert tasks, and rationalism and science have to be pursued in order to systematize the world. Hence education becomes a central feature for society, as an institution per se (Meyer, 1977), but at the same time instrumental to the needs of society and labour ( $v s$ the classical ideal of knowledge as an end in itself). The epistemological approach is different: while for Weber social action is ultimately constructed by single individuals (methodological individualism), for Durkheim the unit of analysis is the social fact.

At this point, it is important to underline that both management studies and higher education studies are applied research areas - but perhaps with different users. While much of the research undertaken in management target firms, for-profit organizations and those working in industry and business (Clegg, 2003), many users of higher education research are found in governments, public agencies and funding organizations (Teichler and Sadlak, 2000). However, there is also a striking similarity between the two research areas. Somewhat ironically, Clegg $(2003,539)$ argued that in management studies numerous sources of knowledge (networks, reflective practitioners, popular books and in-house training) inform practice and that the influence of management researchers on the field of practice is rather limited. The same argument has been made for higher education research (Schwarz and Teichler, 2000). Hence, while the links between research and policy are noticeable, it may be harder for higher education researchers to identify the impact of higher education research on the practice of 
managing universities and colleges, perhaps with Clark's book on entrepreneurial universities as a noticeable exception (see, e.g. Clark, 2004b, 3).

As such, one might ask whether a Weberian perspective may have the paradoxical consequence that the focus on the legal and structural issues of higher education reform somehow de-couples the results from their practical applications within universities and colleges. This may be a consequence of the fact that legal and structural issues downplay processes, and highlight the formal aims and objectives of reform - through its unavoidable rationalization (Weber, 1978). In contrast, a Durkheimian perspective pays much attention to process, social interaction, symbols and moral commitment (Durkheim, 1915) - features that were also heavily emphasized in the 'old' institutional theories of Selznick (1957), and that characterized much of Clark's writings (see, e.g., Clark, 1998, 2004a, b).

\section{The Coverage of Organizational Studies in Higher Education Policy the Last 25 years}

\section{Sampling and method}

For the specific purposes of this special issue, we examined the 25 years of Higher Education Policy existence (1988-2013) and we selected articles according to two criteria. First, we looked at all papers that have at least 20 citations according to Harzing's Publish or Perish index (accessed 19 April 2013). We selected 20 as a reasonable number in order to discuss works that have had impact in the higher education research community. This provided us with a total of 125 articles.

As a second criterion we selected among the 125 articles those containing in their title and/or abstract words that could be linked to organization studies; such as organization, institutional management, institutional strategy, institutional governance, culture and identity, university autonomy. As a result the sample we analysed in detail consisted of 26 articles, summarized in Table 1.

\section{Central research topics}

In general we found that many studies have focused on the link between state and higher education institutions, and the changes in governance modes (see also Jungblut and Vukasovic's contribution elsewhere in this special issue). Shifts on logics of regulation such as market-based contracts, bureaucratically based rules and professionally based norms have been mostly explained by considering policy reforms as determinants of change. On the other hand, fewer studies have addressed the intra-organizational dynamics driving organizational change. In general, our search showed that not many articles published in Higher Education Policy have taken into consideration universities as (single) institutions/organizations and their functioning. 
Table 1 Higher education policy 1988-2013: Most cited articles with an organizational perspective

\begin{tabular}{|c|c|c|c|c|}
\hline Author(s) & Year & Theme $(s)$ & Research question(s) & Approach \\
\hline Cowen & 1991 & $\begin{array}{l}\text { Entrepreneurial university, } \\
\text { institutional management, } \\
\text { accountability }\end{array}$ & $\begin{array}{l}\text { What are characteristics of reform policies towards the entrepreneurial } \\
\text { university, its management and its evaluation? }\end{array}$ & Case study England \\
\hline Trow & 1994 & $\begin{array}{l}\text { Autonomy, managerialism, } \\
\text { accountability }\end{array}$ & $\begin{array}{l}\text { How effective are 'managerialist' policies regarding evaluation of } \\
\text { universities? What are the implications for the university? }\end{array}$ & Case study UK \\
\hline Van Ginkel & 1995 & Organizational change & $\begin{array}{l}\text { How will teaching and research missions interlink in a growing } \\
\text { knowledge-intensive society? }\end{array}$ & Conceptual \\
\hline Lewis, Altbach & 1996 & Academic work, administration & How is the relation between faculty and administration evolving? & International Survey \\
\hline Clark & 1997 & Organizational change & How do/may universities handle multiple and conflicting pressures? & Conceptual \\
\hline Dearlove & $1998 \mathrm{a}$ & $\begin{array}{l}\text { Academic work, administration, } \\
\text { managerialism }\end{array}$ & $\begin{array}{l}\text { How can university management be efficient beyond managerialism } \\
\text { and collegiality? }\end{array}$ & Case study UK \\
\hline Dearlove & $1998 b$ & Institutional governance & $\begin{array}{l}\text { How are university management and governance changing? What are } \\
\text { the implications? }\end{array}$ & Case study UK \\
\hline $\begin{array}{l}\text { de Boer, Denters, } \\
\text { Goedegebuure }\end{array}$ & 1998 & Institutional governance & $\begin{array}{l}\text { How have the relations between representative assemblies and } \\
\text { university executive changed? }\end{array}$ & $\begin{array}{l}\text { Case study The } \\
\text { Netherlands }\end{array}$ \\
\hline Pechar, Pellert & 1998 & Change management & $\begin{array}{l}\text { How have university reforms evolved? Why do such reforms only have } \\
\text { little impact on university functioning? }\end{array}$ & Case study Austria \\
\hline Trow & 1998 & Institutional governance & $\begin{array}{l}\text { How can governance and administration enhance university autonomy } \\
\text { and excellence? }\end{array}$ & $\begin{array}{l}\text { Case study University } \\
\text { of California }\end{array}$ \\
\hline Reponen & 1999 & Institutional leadership & $\begin{array}{l}\text { How can leadership enhance efficiency and productivity in a knowledge } \\
\text { and expert organization like university? }\end{array}$ & Conceptual \\
\hline Hölttä, Malkki & 2000 & Organizational adaptation & $\begin{array}{l}\text { How did universities respond strategically to new accountability } \\
\text { mechanisms? }\end{array}$ & Case study Finland \\
\hline Dill & 2001 & Autonomy, accountability & $\begin{array}{l}\text { How can policies address the link between autonomy and } \\
\text { accountability? }\end{array}$ & Conceptual \\
\hline El Khawas & 2001 & Organizational adaptation & $\begin{array}{l}\text { How do universities respond to challenges such as access, financing, } \\
\text { management and teaching? }\end{array}$ & Conceptual \\
\hline Eckel, Kezar & 2003 & Organizational change & $\begin{array}{l}\text { How can sense-making be used strategically by university leaders in } \\
\text { order to trigger transformational change? }\end{array}$ & $\begin{array}{l}\text { Multiple case study six } \\
\text { US universities }\end{array}$ \\
\hline
\end{tabular}


Table 1 continued

\begin{tabular}{|c|c|c|c|c|}
\hline Author(s) & Year & Theme(s) & Research question(s) & Approach \\
\hline Nybom & 2003 & University as institution & $\begin{array}{l}\text { What are the characteristics of the Humboldtian model? What is its } \\
\text { legacy? }\end{array}$ & Historical, conceptual \\
\hline Clark & 2004a & Entrepreneurial university & $\begin{array}{l}\text { How do entrepreneurial universities emerge and how do they sustain } \\
\text { themselves? }\end{array}$ & Conceptual \\
\hline Navarro, Gallardo & 2003 & Organizational change & $\begin{array}{l}\text { How can universities develop organizational capabilities in order to } \\
\text { adapt to continuous environmental change? }\end{array}$ & Conceptual \\
\hline $\begin{array}{l}\text { Santiago, } \\
\quad \text { Carvalho }\end{array}$ & 2004 & Managerialism & $\begin{array}{l}\text { How does the rhetoric of managerialism influence actors' perceptions } \\
\text { about the goals of higher education? }\end{array}$ & Case study Portugal \\
\hline
\end{tabular}

$$
\text { Carvalho }
$$$$
\text { Rip }
$$

Mehralizadeh

2004 Organizational change

Bleiklie, Kogan $2007 \quad \begin{gathered}\text { autonomy } \\ \text { University as institution }\end{gathered}$

2005 Institutional management, autonomy

\begin{tabular}{|c|c|c|}
\hline Baker, Lenhardt & 2008 & Research university \\
\hline $\begin{array}{l}\text { Deem, Mok, } \\
\text { Lucas }\end{array}$ & 2008 & Research university \\
\hline Hazelkorn & 2008 & Institutional leadership \\
\hline $\begin{array}{l}\text { Mohrman, Ma, } \\
\text { Baker }\end{array}$ & 2008 & Research university \\
\hline
\end{tabular}

How does the rhetoric of managerialism influence actors' perceptions Case study Portugal

What are the implications for research training in the post-modern Conceptual university?

How can change in higher education be conceptualized? How are Case study Iran university funding, quality and organization changing?

How have the values underpinning higher education changed? What are Comparative analysis the implications of related public policies for governance structures? Europe, North

America

How and why are universities not able to implement the research Case study Germany university model?

What are the beliefs, the practices and the implications of the race to the Comparative analysis research university model?

How do higher education leaders respond to rankings? International survey

Europe, Asia

How has the research university model emerged? What are its Conceptual 
Tatiana Fumasoli and Bjørn Stensaker

A large number of the 26 articles analysed focused on state-university relationships, whereby the state is analysed in its two main functions as main funder of higher education, at least in the continental European model, and as producer of policies aimed to reform the sector. Against this backdrop, institutional autonomy is a major topic tackled in order to understand the implications for the academic profession and academic work (Trow, 1994; Dill, 2001; Mehralizadeh, 2005; Bleiklie and Kogan, 2007).

Policy studies looked at the university with an organizational perspective in order to explain the implementation and (partial) failure of reforms (Pechar and Pellert, 1998; Baker and Lenhardt, 2008) or the issues at stake for institutional governance (Trow, 1998; Dearlove, 1998a, b).

New organizational forms of the university are portrayed. In the framework of world class universities (Huisman, 2008), the so-called Emerging Global Model, which depicts the research-intensive university, is conceptualized at institutional level (Mohrman et al., 2008) and at system level (Baker and Lenhardt, 2008; Deem et al., 2008). Bleiklie and Kogan (2007) outline the stakeholder model, which reflects how a shift in societal values has implications for the university. The functions of teaching and research were characterized through the analysis of the Humboldtian traditional model and its implications for present and future (Nybom, 2003), as well as through a critical assessment of knowledge production in modern society (van Ginkel, 1995).

Organizational structures and processes were studied in the light of the academic profession and academic work, characterizing how motivations, identity and selfperceptions of professors, teachers and researchers change according to external pressures (Lewis and Altbach, 1996; Dearlove, 1998a; Deem et al. 2008).

The issues tackling with a more focused approach based on organizational studies appear scattered: leadership in new forms of governance (de Boer et al., 1998), leadership in loosely coupled systems (Reponen, 1999), but also variation in organizational responses (El-Khawas, 2001; Mehralizadeh, 2005), adaptation processes (Clark, 1997; Hölttä and Malkki, 2000; Hazelkorn, 2008) and strategic change management (Eckel and Kezar, 2003; Navarro and Gallardo, 2003) all emerge from the analysis of Higher Education Policy's articles. In this respect, the studies presented relate to different — and somewhat implicit — assumptions with regard to the implications of emerging managerial and leadership roles and structures.

As of approaches and methodology some articles took a normative stance, discussing changes in institutional governance structures to call for a better managed university (Dearlove, 1998b; Reponen, 1999; Dill, 2001). Most analyses are based on a single case study, which usually addresses a national higher education system (see Table 1). Santiago and Carvalho (2004), through the lens of managerialist discourses, critically explored the shift in the underlying higher education values (see also Deem et al., 2008). 
Tatiana Fumasoli and Bjørn Stensaker

Organizational Studies in Higher Education

488

\section{Whose research agenda?}

By focusing the research agenda on policy studies, articles on the transformations of higher education have disregarded somewhat the point of view of practitioners, or, in other words, the needs of those that, within universities and colleges, have to cope with the reforms being implemented. At the same time, distinctive normative positions on the meanings and functions of higher education in society have to some extent led to a conceptually fragmented debate.

First, higher education research can be considered as mainly a problem-driven field (Teichler, 2000, 19). This means that scholars coming from various disciplines investigate higher education but do not necessarily contribute to the conceptual evolution of the domain. Second, higher education research is an applied field (El-Khawas, 2000, 45), hence it addresses practitioners that are involved in the system. These belong to two different groups that have also diverse interests in the outcomes of research. On one side there are policymakers, who are involved in tasks of coordination at national system level, who aim at improving and reforming higher education. On the other side, academic leaders, managers and administrators work within universities and colleges attempting at making them function efficiently and effectively.

The first users of higher education research have been favoured in many aspects, while the second have been somehow neglected, or only indirectly addressed. Against this backdrop, an organizational perspective on higher education research could make an important contribution in that it would open the black box of the university as an organization and provide insight on how its main activities teaching, research and services — are eventually carried out and — to some extent coordinated. This is becoming even more important given the competitive pressures universities are undergoing for funds, students, human resources and reputation.

\section{The Need for a More Systematic and Comprehensive Understanding of Organizational Change}

While our review of articles in Higher Education Policy is too limited to draw general conclusions concerning organizational studies in higher education in general, we would argue that the review does provide some interesting hints about how policy-oriented organizational studies can be strengthened in the years to come. In general, there are different assumptions and theoretical perspectives through which organizational change can be investigated: a focus on the structure/agency nexus in organizational studies, a focus on higher education as an arena for political and policy decisions in political science, and a focus on academic work based on the sociology of professions (Reed et al., 2002).

While the second and third approach have been emphasized in recent years, we would argue that the first perspective is potentially prone to contribute substantially 
Tatiana Fumasoli and Bjørn Stensaker

to our understanding of transformations in higher education by asking how and to what extent universities and colleges are changing on the one hand, and how and to what extent policy reforms influence change processes. In the end shedding light on how reforms produce intended and unexpected outcomes remains a major issue for higher education studies, as well as for policy and public administration studies.

Organization studies are based on numerous distinctive theoretical approaches. The most important perspectives underline how universities and colleges as organizations are affected by their environment. Some scholars conceive of environmental influences as almost deterministic, like in organizational ecology (Hannan and Freeman, 1977), some acknowledge a degree of agency of organizations (Pfeffer and Salancik, 1978). Institutional theory has dynamically evolved along this continuum, focusing in its origin to the dynamics within the organization (Selznick, 1949), then concentrating on external forces (DiMaggio and Powell, 1983), progressively re-integrating (at least partially) issues of power and agency (DiMaggio and Powell, 1991; Scott, 2008). In essence, this development has implied a more coherent view of factors driving organizational change. The latter development is interesting if more policy-oriented organizational research is to be stimulated in the future.

Drawing on a seminal article by Greenwood and Hinings on organizational change (1996), we contend that integrating old and new institutionalism would offer an analytical device combining an approach privileging the influence of the environment on the university (primacy of structure) with a focus on intraorganizational processes shaping university actions (primacy of agency). In this sense, Clark provides a useful point of departure. On one side his perspective sheds light on the complex dynamics at play, taking into consideration structures and processes as well as organizational culture(s). On the other hand he takes into account external influences and how universities and colleges cope with them. Fortunately, there is a growing interest among higher education researchers and beyond studying universities and colleges as organizational actors (see, for example, a special issue of Higher Education, 2013; a special issue of the Cambridge Journal of Economics, 2012; Krücken and Meier, 2006; Whitley, 2008).

While these efforts should be seen as valuable contributions to organizational research in higher education, we have in the first part of this article tried to illustrate that there is a need to better understand the organizational transformation of the university because of the implications of reforms granting universities more institutional autonomy. In doing so, we could provide an improved analytical link between university and environment that goes beyond state-university relationships and beyond the conceptualization of university as an organized anarchy or as a specific organization (Cohen and March, 1974; Musselin, 2006). This perspective has a number of implications for the analytical framework and the methodology in studying change in universities and colleges. Below we highlight some of the most important. 
Tatiana Fumasoli and Bjørn Stensaker

Organizational Studies in Higher Education

490

\section{Process combined with structure}

Increasing attention to the organizing dimension of the university (process) could be given (Weick, 1979). Exploring such processes within the university in order to understand the dynamics of change would give an insight into what happens within the university and how this has implications for higher education in general. We need to explore the link between organizing and the primary processes of education and research in more detail. While much organizational research in higher education has focused on structures and formal power shifts between hierarchical levels in the university, we have far fewer studies on how organizing influence the content and practices of teaching or the inner life of research. While much output data are currently produced in both areas, we know surprisingly little about the production processes as such. Such a shift would also have implications for the research design as processes have to be observed over time possibly through participant observation and other ethnographic methods.

\section{The university in the organizational field}

Considering the university or college as a unit of analysis implies that the dimension of change to be analysed is organizational ( $v s$ policy-related). This entails a shift in dependent and independent variables. For instance, structural change (previously a dependent variable) becomes a determinant of change in practices. At the same time, depending on the research question, change in practices could be considered a factor of change in the higher education field, thus the link between micro and macro is established (Greenwood and Hinings, 1996; Feldman and Pentland, 2003). In general terms, the organization should be conceptualized and operationalized as an open system, which interrelates mutually with its environment while a bottom-up perspective should be favoured in order to capture more subtly the dynamics of change.

\section{Instrument $v s$ institution}

The debate on changes in higher education has focused on the ongoing forces pushing for transformation of the university from an institution within society to an instrument of society (see for instance Leslie and Slaughter, 1999 on academic capitalism). The different logics at work coexisting in contemporary higher education have implications for universities and colleges and the way they function (see Thornton and Ocasio, 1999 on shifting logics in academic publishing). Studying the complex nexus structure - agency can shed light on organizational dynamics of change, taking into consideration the organization as an open system, thus constituted of linkages with its environment and taking into consideration the internal dynamics that trigger organizational change, 'The action of values, interests, power, and capacity within an organization must be brought into play' (Greenwood and Hinings, 1996, 1048).

Higher Education Policy 201326 
Tatiana Fumasoli and Bjørn Stensaker

\section{Revised research designs}

Our suggestions may also have quite dramatic consequences for research design and methodological framing of future research. Given the tradition and the history surrounding higher education, there are only few historical studies of change in the sector although such studies could have much potential (Tight, 2012). For example, historical studies show that the current focus on strategy perhaps is not so different from the former 'planning era' (Keller, 1983). Furthermore, much research approaches strategy in a top-down manner and assumes intentionality by management as the central driver. Recent works addressing management in higher education (Duderstadt, 2000; MacCaffery, 2010; Toma, 2010) posit — implicitly or explicitly — rationality of institutional leadership in changing the university through organizational design. Interestingly, these contributions have been challenged by researchers emphasizing the importance of day-to-day activities in universities and how practice and culture affect the translations of strategic processes (Jarzabkowski, 2004; Stensaker et al., 2012).

In a similar vein, processes can be observed by addressing organizational routines, which are codified practices within the university that play a distinctive role in processes of organizational change. They evolve over time according to the specific conditions under which they are enacted, following reorganization or external shocks, but they can also represent a source of endogenous change (Feldman and Pentland, 2003). At the same time, organizational routines are a primary target of strategy, for it is through (attempts at) changing structures and processes that strategy is carried out (Teece et al., 1997). How do organizational routines evolve and interact with reforms and strategy? How do organizational routines affect the outcomes of reforms and strategies? How do organizational routines bring about organizational change?

In sum, we contend that a thorough organizational perspective on higher education has to consider first of all the above-mentioned analytical dimensions to broaden the perspective and linking organization and its environment (i.e. organizational field) in a reciprocal relationship by characterizing the relevant mechanisms. We call for an understanding of change as 'a complex ecology' (Gornitzka et al., 2007) with unanticipated consequences (Merton, 1936) rather than unidirectional change by design (Olsen, 2009).

\section{Conclusion}

Traditionally universities have been considered loosely coupled systems (Weick, 1976) where subunits are almost autonomous, and where there is little coordination and control by central management. In addition, as organized anarchies (Cohen and March, 1974), universities' core activities have been characterized by ambiguity and unclearness (see also Musselin, 2006). However, observed change concerning 
centralization, standardization and formalization within universities, although with different pace and extent in different contexts, might have stretched, extended and modified the idea of loosely coupled system. While the current university can hardly be described as an organized anarchy, it is also difficult to portray the university as a rational actor (but see Krücken and Meier, 2006). We need to explore more closely the gaps between these opposing explanations as we believe more convincing understanding for organizational change can be developed if we take into account the complexity of the university as an organization. What are the implications of this organizational change within universities and colleges? How can variations be explained?

The sustainability of universities and colleges is becoming a major concern due to competition for funding, students, academic staff and due to the pressure to comply with quality requirements and accountability demands. This means that not only winners will emerge but also losers. In this sense higher education researchers should take into account long-term viability of universities. Here, an organizational perspective could allow for delving into the factors, dynamics and outcomes of (temporary) breakdown while at the same time could better detect, by comparison, the determinants of success.

To account for this complexity, our answer is to find a middle way between Weber's and Durkheim's traditions and by balancing the insights from old and new institutionalism in order to get a more accurate view on dynamics of organizational change in the sector. As Burton Clark himself pointed out in a personal conversation a decade ago; 'It seems eminently sensible that if we want to find out how universities change, we ought to concentrate research on specific exemplars of organizational transformation ... . I like actors whom I can see and touch, rather than the wispy general norms of a larger organizational field that supposedly lock universities in iron cages of conformity. The latter is particularly insensitive to transforming change' (Clark, 2004c). The added value of this approach is that - we would argue - higher education research will be able to provide a better contribution to practitioners (policymakers, managers and administrators), to its scientific community as well as to related disciplines such as sociology, political science, management and organization studies.

\section{References}

Altbach P. (ed.) (1996) The International Academic Profession. Portraits of Fourteen Countries, Princeton: Carnegie Foundation.

Amaral A., Jones G. and Karseth B. (eds.) (2002) Governing Higher Education: National Perspectives on Institutional Governance, Dordrecht: Kluwer Academic Publishers.

Amaral A., Meek V.L. and Larsen I.M. (eds.) (2003) The Higher Education Managerial Revolution?, Dordrecht: Kluwer Academic Publishers.

Baker, D.P. and Lenhardt, G. (2008) 'The institutional crisis of the German research university', Higher Education Policy 21(1): 49-64. 
Baldridge, J.V. (1971) Power and Conflict in the University: Research in the Sociology of Complex Organizations, London: J. Wiley.

Bleiklie, I. and Kogan, M. (2007) 'Organization and governance of universities', Higher Education Policy 20(4): 477-493.

Bleiklie, I., Enders, J. and Lepori, B. (2013) Higher Education, Special Issue: Transforming Universities in Europe 65(1): 1-151.

Braun, D. and Merrien, F.-X. (1999) Towards a New Model of Governance for Universities?: A Comparative View, London: Jessica Kingsley.

Clark, B.R. (1956) 'Organizational adaptation and precarious values: A case study', American Sociological Review 21(3): 327-336.

Clark, B.R. (1960) The Open Door College: A Case Study, New York: McGraw-Hill.

Clark, B.R. (1970) The Distinctive College, Chicago, IL: Aldine.

Clark, B.R. (1972) 'The organizational saga in higher education', Administrative Science Quarterly 17(2): 178-184.

Clark, B.R. (1997) 'Common problems and adaptive responses in the universities of the world: Organizing for change', Higher Education Policy 10(3/4): 291-295.

Clark, B.R. (1998) Creating Entrepreneurial Universities: Organizational Pathways of Transformation, New York: International Association of Universities Press/Pergamon — Elsevier Science.

Clark, B.R. (2004a) 'Delineating the character of the entrepreneurial university', Higher Education Policy 17(4): 355-370.

Clark, B.R. (2004b) Sustaining Change in Universities, Berkshire: SHRE/Open University Press.

Clark, B.R. (2004c) Personal communication (e-mail, dated 19 July).

Clegg, S. (2003) 'Managing Organizational Futures in a Changing World of Power/Knowledge', in H. Tsoukas and C. Knudsen (eds.) The Oxford Handbook of Organizational Theory. Meta-theoretical Perspectives, Oxford: Oxford University Press, pp. 536-567.

Cohen, M.D. and March, J.G. (1974) Leadership and Ambiguity: The American College President, Columbus, OH: McGraw-Hill.

Cowen, R. (1991) 'The management and evaluation of the entrepreneurial university: The case of England', Higher Education Policy 4(3): 9-13.

Dearlove, J. (1998a) 'The deadly dull issue of university "administration"? Good governance, managerialism and organising academic work', Higher Education Policy 11(1): 59-79.

Dearlove, J. (1998b) 'Fundamental changes in institutional governance structures: The United Kingdom', Higher Education Policy 11(2/3): 111-120.

Deem, R., Mok, K.H. and Lucas, L. (2008) 'Transforming higher education in whose image? Exploring the concept of the "world-class" university in Europe and Asia', Higher Education Policy 21(1): 83-97.

Deiaco, E., Hughes, A. and McKelvey, M. (eds.) (2012) 'Special issue: universities as strategic actors in the knowledge economy', Cambridge Journal of Economics 36(3): 525-780.

Dill, D.D. (2001) 'The regulation of public research universities: Changes in academic competition and implications for university autonomy and accountability', Higher Education Policy 14(1): 21-35.

DiMaggio, P.J. and Powell, W.W. (1983) 'The iron cage revisited — institutional isomorphism and collective rationality in organizational fields', American Sociological Review 48(2): 147-160.

DiMaggio P.J. and Powell W.W. (eds.) (1991) New Institutionalism in Organizational Analysis, Chicago, IL: University of Chicago Press, pp. 1-38.

de Boer, H., Denters, B. and Goedegebuure, L. (1998) 'On boards and councils; shaky balances considered the governance of Dutch universities', Higher Education Policy 11(2/3): 153-164.

Duderstadt, J.J. (2000) A University for the 21st Century, Ann Arbor: The University of Michigan Press.

Durkheim, E. (1915) The Elementary Forms of Religious Life, New York: Free Press.

Eckel, P.D. and Kezar, A. (2003) 'Key strategies for making new institutional sense: Ingredients to higher education transformation', Higher Education Policy 16(1): 39-53. 
El-Khawas, E. (2000) 'Patterns of Communication and Miscommunication Between Research and Policy', in S. Schwarz and U. Teichler (eds.) The Institutional Basis of Higher Education Research. Experiences and Perspectives, Dordrecht: Kluwer Academic Publishers, pp. 45-56.

El-Khawas, E. (2001) 'Today's universities: Responsive, resilient, or rigid?', Higher Education Policy 14(3): 241-248.

Estermann, T. and Nokkala, T. (2009) University Autonomy in Europe I. Exploratory Study, Brussels: European University Association.

Estermann, T., Nokkala, T. and Steinel, M. (2011) University Autonomy in Europe II. The Scorecard, Brussels: European University Association.

Feldman, M.S. and Pentland, B.T. (2003) 'Reconceptualizing organizational routines as a source of flexibility and change', Administrative Science Quarterly 48(1): 94-118.

Gornitzka, Å., Maassen, P., Olsen, J.P. and Stensaker, B. (2007) 'Europe of Knowledge': Search for a New Pact', in P. Maassen and J.P. Olsen (eds.) University Dynamics and European Integration, Dordrecht: Springer, pp. 181-214.

Greenwood, R. and Hinings, C.R. (1996) 'Understanding radical organizational change: Bringing together the old and the new institutionalism', Academy of Management Review 21(4): 1022-1054.

Hannan, M.T. and Freeman, J. (1977) 'The population ecology of organizations', The American Journal of Sociology 82(5): 929-964.

Hazelkorn, E. (2008) 'Learning to live with league tables and ranking: The experience of institutional leaders', Higher Education Policy 21(2): 193-215.

Hölttä, S. and Malkki, P. (2000) 'Response of Finnish higher education institutions to the national information society programme', Higher Education Policy 13(3): 231-243.

Huisman, J. (2008) Higher Education Policy, Special Issue: World Class Universities 21(1): 1-146.

Huisman J. (ed.) (2009) International Perspectives on the Governance of Higher Education. Alternative Frameworks for Coordination, New York: Routledge.

Jarzabkowski, P. (2004) 'Strategy as practice: Recursiveness, adaptation, and practices-in-use', Organization Studies 25(4): 529-560.

Kehm, B. and Lanzendorf, U. (2006) Reforming University Governance: Changing Conditions for Research in Four European Countries, Berlin: Lemmens.

Kehm, B. and Teichler, U. (2013) The Academic Profession in Europe: New Tasks and New Challenges, Dodrecht: Springer.

Keller, G. (1983) Academic Strategy, Baltimore, MD: The Johns Hopkins University Press.

Krücken, G. and Meier, F. (2006) 'Turning the University into an Organizational Actor', in G.S. Drori, J. W. Meyer and H. Hwang (eds.) Globalization and Organization. World Society and Organizational Change, Oxford: Oxford University Press, pp. 209-240.

Leslie, L.L. and Slaughter, S. (1999) Academic Capitalism. Politics, Policies, and the Entrepreneurial University, Baltimore, MD: Johns Hopkins University Press.

Lewis, L.S. and Altbach, P.G. (1996) 'Faculty versus administration: A universal problem', Higher Education Policy 9(3): 255-258.

Locke, W., Cummings, W.K. and Fisher, D. (2011) Changing Governance and Management in Higher Education. The Perspectives of the Academy, Dordrecht: Springer.

MacCaffery, P. (2010) The Higher Education Manager's Handbook: Effective Leadership and Management in Universities and Colleges, New York: Routledge.

Maassen, P. and Olsen, J.P. (2007) University Dynamics and European Integration, Dodrecht: Springer.

Mehralizadeh (2005) 'New reforms in the management of the university: Transition from centralized to decentralized (university-based management) in Iran', Higher Education Policy 18(1): 67-82.

Merton, R.K. (1936) 'The unanticipated consequences of purposive social action', American Sociological Review 1(6): 894-904.

Meyer, J.W. (1977) 'The effects of education as an institution', American Journal of Sociolog 83(1): 55-77.

Higher Education Policy 201326 
Mohrman, K., Ma, W. and Baker, D. (2008) 'The research university in transition: The emerging global model', Higher Education Policy 21(1): 5-27.

Musselin, C. (2001) La Longue Marche Des Universités Françaises, Paris: Presses universitaires de France.

Musselin, C. (2006) 'Are Universities Specific Organizations?', in G. Krücken, A. Kosmützky and M. Torka (eds.) Towards a Multiversity? Universities between Global Trends and National Traditions, Bielefeld: Transcript, pp. 63-84.

Navarro, J.R. and Gallardo, F.O. (2003) 'A model of strategic change: Universities and dynamic capabilities’, Higher Education Policy 16(2): 199-212.

Nybom, T. (2003) 'The Humboldt legacy: Reflections on the past, present, and future of the European university', Higher Education Policy 16(2): 141-159.

Oliver, C. (1991) 'Strategic responses to institutional processes', The Academy of Management Review 16 (1): $145-179$.

Olsen, J.P. (2009) 'Democratic government, institutional autonomy and the dynamics of change', West European Politics 32(3): 439-465.

Paradeise, C., Reale, E., Bleiklie, I. and Ferlie, E. (2009) University Governance Western European Comparative Perspectives, Dordrecht: Springer.

Pechar, H. and Pellert, A. (1998) 'Managing change: Organizational reform in Austrian universities', Higher Education Policy 11(2/3): 141-151.

Pfeffer, J. (1997) New Directions for Organization Theory : Problems and Prospects, New York: Oxford University Press.

Pfeffer, J. and Salancik, G.R. (1978) The External Control of Organizations: A Resource Dependence Perspective, New York: Harper \& Row.

Reed, M., Meek, V.L. and Jones, G. (2002) 'Introduction', in A. Amaral, G. Jones and B. Karseth (eds.) Governing Higher Education: National Perspectives on Institutional Governance, Dordrecht/Boston, MA/London: Kluwer Academic Publishers, pp. xv-xxxi.

Reponen, T. (1999) 'Is leadership possible at loosely coupled organizations such as universities?', Higher Education Policy 12(3): 247-254.

Rip, A. (2004) 'Strategic research, post-modern universities and research training', Higher Education Policy 17(2): 153-166.

Salancik, G.R. and Pfeffer, J. (1974) 'The bases and use of power in organizational decision making: The case of a university', Administrative Science Quarterly 19(4): 453-473.

Santiago, R.A. and Carvalho, T. (2004) 'Effects of managerialism on the perceptions of higher education in Portugal', Higher Education Policy 17(4): 427-444.

Schwarz, S. and Teichler, U. (2000) The Institutional Basis of Higher Education Research. Experiences and Perspectives, Dordrecht: Kluwer Academic Publishers.

Scott, W.R. (2008) Institutions and Organizations. Ideas and Interests, Thousand Oaks, CA: Sage.

Selznick, P. (1949) TVA and the Grass Roots: A Study in the Sociology of Formal Organization, Berkeley, CA: University of California Press.

Selznick, P. (1957) Leadership in Administration. A Sociological Interpretation, New York: Harper \& Row Publishers.

Stensaker B., Välimaa J. and Sarrico C. (eds.) (2012) Managing Reform in Universities. The Dynamics or Culture, Identity and Organizational Change, Basingstoke: Palgrave Macmillan.

Teece, D.J., Pisano, G. and Shuen, A. (1997) 'Dynamic capabilities and strategic management', Strategic Management Journal 18(7): 509-533.

Teichler, U. (2000) 'Higher Education Research and its Institutional Basis', in S. Schwarz and U. Teichler (eds.) The Institutional Basis of Higher Education Research. Experiences and Perspectives, Dordrecht: Kluwer Academic Publishers, pp. 13-24.

Teichler, U., Arimoto, A. and Cummings, W.K. (2013) The Changing Academic Profession: Major Findings of a Comparative Survey, London: Springer. 
Teichler U. and Sadlak J. (eds.) (2000) 'Higher Education Research and its relation to Policy and Practise' Oxford: Pergamon/IAU Press.

Teixeira, P., Jongbloed, B., Dill, D.D. and Amaral, A. (2004) Markets in Higher Education. Rhetoric or Reality?, Dordrecht: Springer.

Thornton, P.H. and Ocasio, W. (1999) 'Institutional logics and the historical contingency of power in organizations: Executive succession in the higher education publishing industry, 1958-1990', American Journal of Sociology 105(3): 801-843.

Tight, M. (2012) Researching Higher Education, Maidenhead, England: Open University Press.

Toma, J.D. (2010) Building Organizational Capacity: Strategic Management in Higher Education, Baltimore, MD: Johns Hopkins University Press.

Trow, M. (1994) 'Managerialism and the academic profession: The case of England', Higher Education Policy 7(2): 11-18.

Trow, M. (1998) 'Governance in the university of California: The transformation of politics into administration', Higher Education Policy 11(2/3): 201-215.

Van Ginkel, H. (1995) 'University 2050: The organization of creativity and innovation', Higher Education Policy 8: 14-18.

Weber, M. (1978) Economy and Society, Berkeley, CA: University of California Press.

Weick, K. (1976) 'Educational organizations as loosely coupled systems', Administrative Science Quarterly 21(1): 1-19.

Weick, K. (1979) The Social Psychology of Organizing, New York: Random House.

Whitley, R. (2008) 'Universities as Strategic Actors: Limitations and Variations', in L. Engwall and D. Weaire (eds.) The University in the Market, London: Portland Press, pp. 22-37. 